\title{
Management of chronic neuritis with an extended and continuous course of prednisolone and methotrexate: A case report
}

\author{
Delwar Hossain \\ Department of Dermatology and Venereology, University of Science and Technology Chittagong (USTC), Chittagong, Bangladesh
}

\section{Email address:}

delwar_ustc@yahoo.co.uk

\section{To cite this article:}

Delwar Hossain. Management of Chronic Neuritis with an Extended and Continuous Course of Prednisolone and Methotrexate: A Case Report. American Journal of Clinical and Experimental Medicine. Vol. 2, No. 6, 2014, pp. 171-174. doi: 10.11648/j.ajcem.20140206.20

\begin{abstract}
Patients may have prolonged neuritic episode in the field of leprosy. In that case, one or few interrupted courses of prednisolone of 4-months duration may prove inadequate for the unduly suffering patients. With an intention to see whether a prolonged course of prednisolone and methotrexate could be of any help for them, a patient having neuritis in several nerves including multiple abscesses in the right sural nerve was treated with a 15 months extended and continuous course of prednisolone and methotrexate. The outcome was complete and permanent remission with full functional recovery. Few mild self-limiting side effects from prednisolone were seen. However, there was no side effect from methotrexate. In conclusion, extended and continuous course of prednisolone and methotrexate was found safe and effective in treating a case of chronic neuritis.
\end{abstract}

Keywords: Leprosy, Chronic neuritis, Treatment, Prednisolone, Methotrexate

\section{Introduction}

Neuritis is an episodic inflammation of nerve. In chronic neuritis of reversal reaction ${ }^{1}$, there would be chronic inflammatory cells infiltrate, the granulomatous reaction of which could cause direct damage to axon and Schwann cells, and associated edema could cause further damage to nerve by increasing intra-neural pressure and compromising circulation. Finally, post-inflammatory fibrosis also plays a pivotal role in continuing nerve damage. Thus, neuritis persisting for more than 6 months may be defined as chronic neuritis.

To date, prednisolone is the drug of choice for its management. A four months course of it works fairly well in the majority cases. However, particularly in case of some patients with chronic neuritis, it may not work. Thus, patient may suffer unduly.

Combination of prednisolone and methotrexate was found synergistic in anti-inflammatory function ${ }^{2}$. This combination was also found helpful in managing resistant ENL reaction ${ }^{3}$. Thus, this regimen in therapeutic clinical trial for chronic neuritis was chosen.

\section{The Case}

A male of 30 years attended a leprosy clinic in April, 2007 with the complaint of reddish anesthetic patch over right dorsal and lateral foot. He also had mildly enlarged, painfultender right common peroneal, posterior tibial and sural nerves with three standard points anesthesia over lateral sole. His slit skin smear test was negative. He was diagnosed as borderline tuberculoid (BT) leprosy with neuritis and was put on MDT-MB (multidrug therapy-multibacillary) for twelve months and prednisolone with an initial dose of $40 \mathrm{mg}$ per day with fortnightly tapering to end the course within the next four months.

In the first year, he completed his MDT course and received two 4-monthly steroid courses. He noticed skin lesion subsided leaving a pale shiny hypesthetic patch behind and one standard point on heel regained sensation. His painful tender nerves remained quiescent while he was on higher doses (>20 mg per day) of prednisolone, remained tolerable at lower doses and symptoms free time was only few days to a week without steroid.

During the next two years he received a few 4-months courses of prednisolone. Overall outcome of neuritis was 
found more or less same except one standard point on lateral sole that regained its sensation. In addition, he experienced development of reddish papules over his face, neck and trunk, worsening of his gastric pain and gained weight from higher doses of prednisolone. Being frustrated and disappointed, he left leprosy clinic and was on and off self medication (prednisolone) for the next 3-years. During this time, he developed right dorsal foot ulcer (perhaps from sural abscess) that healed with a scar. He also developed two dark rough small plaques along right lateral leg and dorsal foot insidiously and pink swollen discharging plaque over right arch of foot. He was then diagnosed as cellulitis and received several prolonged courses of antibiotics without any benefit. He visited many physicians and general hospitals for magic cure and finally he came back to the clinic.

On examination, severely enlarged (more than several times normal and visible as cord under skin), severely painful (disturbing night sleep and discomfort at normal walk) and severely tender (uttering Oh! Ah! And changing facial expression at palpation of nerves) right common peroneal, posterior tibial and sural nerves with shooting pain along the courses of said nerves were found. There were also leg muscle cramps, swollen right ankles, two plaques along the course of sural nerve, a pale hypesthetic patch with an old scar over dorsal lateral foot. A pink swollen serous discharging plaque was found over center of right sole (Fig1A). He was otherwise healthy but apprehensive and anxious. His sensory test, quick muscle test and slit skin smear test were done as per the World Health Organization (WHO)guidelines for the field staff. His routine blood, urine and stool tests were normal and serological test for ANA (antinuclear antibody), ds DNA (double stranded deoxyribonucleic acid antibody) and RA (rheumatoid arthritis) factor were negative. His liver/kidney function tests and serum electrolytes were within the normal limit. He denied nerve and sole skin biopsy. In diagnosis he was found having multiple neuritis with multiple sural nerve abscesses (perhaps from reversal reaction).

He was prescribed to take oral prednisolone of $40 \mathrm{mg}$ per day for the first month, then $30 \mathrm{mg}$ per day for the next two months and $20 \mathrm{mg}$ per day for the next 3 months and still then $5 \mathrm{mg}$ tapering quarterly together with oral methotrexate, $2.5 \mathrm{mg}$ for every 12-hours, three doses weekly for 15 months (March, 2013-May, 2014). Monthly clinical follow up was also continued during his treatment.

By the end of the third month's treatment, muscle cramps disappeared, shooting pain along the nerves was gone, discharge from the sole was stopped and nerve tenderness was reduced. During this time, the patient noticed worsening of gastric discomfort, appearance of reddish papules over upper trunk, neck and forehead and feeling of weakness and decreased libido. During the next three months, appearance of foot was improved, dorsal foot plaques size was reduced, sole plaque got flattened to pinkish patch (Fig-1B), nerves size and tenderness were more reduced, consistency was improved and all the side effects of prednisolone were disappeared. During the next three months, nerve tenderness and redness of sole lesion went off. By ninth through twelfth month(s), reduction in size was marked, normal consistency of nerves and normal sensation of dorsal foot lesion were regained and lastly the point of lateral sole got returned (Table-1). There was no side effect from methotrexate. Since then he is fine till to date.

This case was approved as project proposal by the Institutional Review Board of the University in the outdoor clinic where he was treated.

Table 1. Assessing inflamed nerve and its function during anti-neuritis treatment.

\begin{tabular}{|c|c|c|c|c|c|c|}
\hline Parameter & $\begin{array}{l}40 \mathrm{mg} / \text { day } \\
1 \mathrm{month}\end{array}$ & $\begin{array}{l}30 \mathrm{mg} / \text { day } \\
2 \text { months }\end{array}$ & $\begin{array}{l}20 \mathrm{mg} / \mathrm{day} \\
3 \text { months }\end{array}$ & $\begin{array}{l}15 \mathrm{mg} / \mathrm{day} \\
3 \text { months }\end{array}$ & $\begin{array}{l}10 \mathrm{mg} / \text { day } \\
3 \text { months }\end{array}$ & $\begin{array}{l}5 \mathrm{mg} / \mathrm{day} \\
3 \mathrm{months}\end{array}$ \\
\hline $\begin{array}{l}\text { Size } \\
\text { (enlargement) }\end{array}$ & $\begin{array}{l}\text { Reducing from severe } \\
\text { enlargement. }\end{array}$ & $\begin{array}{l}\text { Reducing from severe } \\
\text { enlargement. }\end{array}$ & $\begin{array}{l}\text { Reducing from } \\
\text { moderate } \\
\text { enlargement. }\end{array}$ & $\begin{array}{l}\text { Reducing from } \\
\text { moderate } \\
\text { enlargement. }\end{array}$ & Mild enlarged. & Mild enlarged. \\
\hline Consistency & $\begin{array}{l}\text { Consistency changing } \\
\text { from hard to firmer. }\end{array}$ & $\begin{array}{l}\text { Consistency changing } \\
\text { from hard to firmer. }\end{array}$ & $\begin{array}{l}\text { Consistency changing } \\
\text { from firmer to firm. }\end{array}$ & $\begin{array}{l}\text { Consistency } \\
\text { changing from } \\
\text { firmer to firm. }\end{array}$ & $\begin{array}{l}\text { Firm } \\
\text { consistency. }\end{array}$ & $\begin{array}{l}\text { No further } \\
\text { change in } \\
\text { consistency. }\end{array}$ \\
\hline Tenderness & $\begin{array}{l}\text { Improving from Oh! } \\
\text { Ah! to eye blenching } \\
\text { and shooting pain } \\
\text { reducing. }\end{array}$ & $\begin{array}{l}\text { Improving from Oh! } \\
\text { Ah! to eye blenching } \\
\text { and shooting pain } \\
\text { reducing. }\end{array}$ & $\begin{array}{l}\text { Slight eye blenching } \\
\text { noticed and shooting } \\
\text { pain disappeared. }\end{array}$ & $\begin{array}{l}\text { Slight eye } \\
\text { blenching noticed. }\end{array}$ & Normal feeling. & Normal feeling. \\
\hline $\begin{array}{l}\text { Function } \\
\text { (sensory) }\end{array}$ & No change. & $\begin{array}{l}\text { Sensory function } \\
\text { Improving. }\end{array}$ & $\begin{array}{l}\text { Further improvement } \\
\text { in sensory function. }\end{array}$ & $\begin{array}{l}\text { Further } \\
\text { improvement in } \\
\text { sensory function. }\end{array}$ & $\begin{array}{l}\text { Functional } \\
\text { recovery is } \\
\text { complete. }\end{array}$ & $\begin{array}{l}\text { Normal sensory } \\
\text { function. }\end{array}$ \\
\hline
\end{tabular}

Size: mild enlargement: double the normal size; moderate enlargement: triple the normal size; severe enlargement: 4 or more times than normal size. Tenderness: severe: uttering Oh! Ah! at palpation; moderate: facial expression change and eye blenching at palpation; mild: eye blenching at palpation. 


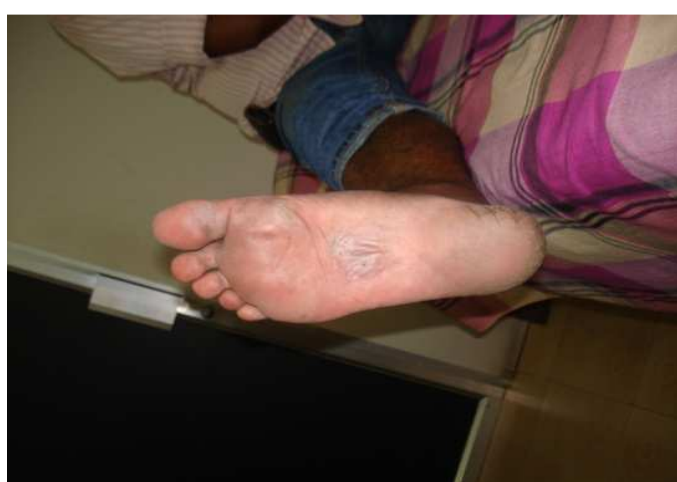

A

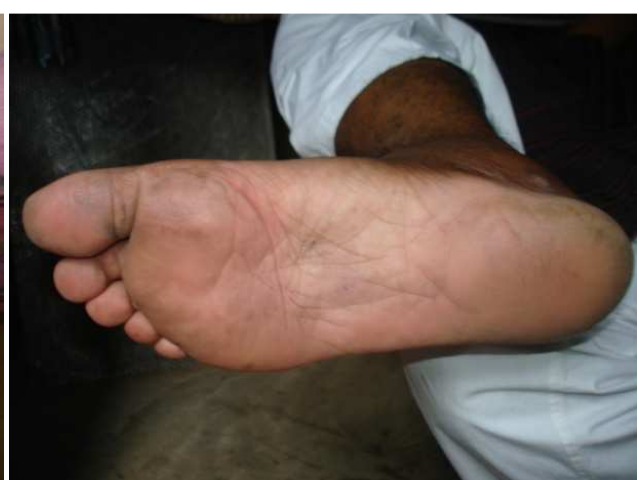

B

Fig 1. (A and B): There is a pinkish plaque with few discharging mouths and peripheral scaling over center of the sole. Same patient after five months with treatment, central sole lesion is disappearing.

\section{Discussion}

A borderline tuberculoid patient had been suffering from chronic neuritis. Protracted response was being seen with multiple interrupted courses of 4-months prednisolone. Complete and persistent remission with full functional recovery was achieved with fifteen months course of prednisolone and methotrexate.

The disease was a chronic neuritis and prolonged natural course was its characteristic feature. Moreover, he was a BT patient and should have more than 4-months prednisolone for his neuritis ${ }^{4-5}$. Unfortunately, the country's national guidelines which were adopted from the WHO-guidelines did not allow field staff(s) to do so. Thus, there was no benefit from multiple interrupted 4-months courses of prednisolone. In that case, though the clinical regimen was prolonged, the natural course of the disease might have been covered and beneficial effect to the patient was evidenced.

Transient and incomplete response to prednisolone was observed. Perhaps, poor efficacy ${ }^{\mathbf{6}}$ and rapid tapering of prednisolone was responsible for this phenomenon. Slow tapering in the clinical regimen might have allowed a certain dose to exert its effect to the full extent and helped complete resolution of inflammation and brought persistent remission with full functional recovery.

His neuritis was relentlessly progressive and silently damaging, perhaps, due to ongoing inflammation in nerves ${ }^{7}$. Prednisolone mono-therapy was proved inadequate. According to the clinical regimen, a combination of prednisolone and methotrexate was able to stop the progression and damage indicating room for combination therapy in managing chronic neuritis.

Symptomatic relief was one of the denominators of dose tapering in WHO-guidelines. In this case, dose tapering was correlated not only with symptomatic relief but also with the status of the inflamed nerve (size, consistency, tenderness and function). Therefore, this approach may be considered as objective, scientific and more helpful in proper management of chronic neuritis in the field situation.

In the study, few self-limiting side effects were seen in the clinical regimen and which were similar to the side-effects of the previous higher doses prednisolone therapy.

Prednisolone protects Schwann cell and axon from direct damage and protects nerve function by reducing edema and fibrosis $^{8}$. Methotrexate can suppress lymphocyte proliferation, reduce production of pro-inflammatory cytokines and increase production of anti-inflammatory cytokines and modulate neutrophil chemotaxis'. It also has anti-fibrotic fuction $^{\mathbf{1 0}}$. Therefore, their synergistic manipulating effects on inflammatory cells, edema and fibrosis may be considered as the resolution of inflammation and remission of the disease though exact cause is not known.

In conclusion, extended and continuous course of prednisolone and methotrexate was found effective and safe in managing a chronic neuritis patient. Formal study is welcomed.

\section{Acknowledgement}

I express my sincere and honest gratitude to Professor Surajit Sarbabidya, Ph D for having great empathy for the chronic sufferers, and his interest and encouragement for the study.

\section{References}

[1] Job CK. Nerve damage in reversal reaction. Ind J Lepr, 1996; 68: 43-47.

[2] Kar BR, Babu R. Methotrexate in resistant ENL. Int J Lepr Other Mycobact Dis, 2004; 72: 4: 480-82.

[3] Delwar Hossain. Using methotrexate to treat patients with ENL unresponsive to steroid and clofazimine: A report on 9 patients. Lepr Rev, March, 2013; 84 (1): 105-112.

[4] Stephen L. Walker and Diana N. J. Lockwood. Leprosy type 1 (reversal) reactions and their management. Lepr Rev, 2008; 79: 372-386.

[5] Rose P, Waters MFR. Reversal reaction in leprosy and their management. Lepr Rev, 1991; 62: 113-21.

[6] Einar P Wilder-Smith and Wim H Van Brakel. Nerve damage in leprosy and its management. Nature Clinical Practice, 2008; 4: 656-663. 
174 Delwar Hossain: Management of Chronic Neuritis with an Extended and Continuous Course of Prednisolone and Methotrexate: A Case Report

[7] David M. Scollard. The biology of nerve injury in leprosy. Lepr Rev, 2008; 79: 242-253.

[8] Naafs B. Treatment of reactions and nerve damage. Int J Lepr, 1996; 64: S21-28.
[9] Swierkot J, Szechinski J. Methotrexate in rheumatoid arthritis. Pharmacol Rep, 2006; 58: 473-92.

[10] Onwukwe MF. Treating keloids by surgery and methotrexate. Arch Dermatol, 1980; 116: 158. 